\title{
A Review on the Important Aspects of Lipase Immobilization on Nanomaterials
}

\author{
Weitao Shuai ${ }^{1,2}$, Ratul Kumar Das ${ }^{2}$, Mitra Naghdi ${ }^{2}$, Satinder Kaur Brar ${ }^{2 *}$ and Mausam \\ Verma $^{3}$
}
${ }^{1}$ College of Environmental Sciences and Engineering, Peking University No.5 Yiheyuan Road, Haidian District, Beijing, China 100871.

${ }^{2}$ INRS-ETE, Université du Québec, 490 Rue de la Couronne, Québec (QC) G1K 9A9, Canada.

${ }^{3} \mathrm{CO}_{2}$ Solutions Inc., 2300, rue Jean-Perrin, Québec, Québec G2C 1T9 Canada

* Corresponding author. Tel.: 418654 3116; Fax: 4186542600

E-mail address: satinder.brar@ete.inrs.ca (S.K. Brar).

Abbreviations: S-NSM: surface-modified nano-sized magnetite; NSM: nano-sized magnetite; PPL: porcine pancreas lipase; SDS: sodium dodecyl sulfate; CRL: Candida rugosa lipase; NHS: N-hydroxysuccinimide; MWCNTs: multi-walled carbon nanotubes; M-MWCNTs: magnetic multi-walled carbon nanotubes; GA: glutaraldehyde; MSNTs: Mesoporous silica nanotubes; PAN: polyacrylonitrile; PBR: Packed bed reactor; PVC: polyvinyl chloride; NSD: nano-silica dioxide; PANCMA: poly-(acrylonitrile-co-maleic acid);

This article has been accepted for publication and undergone full peer review but has not been through the copyediting, typesetting, pagination and proofreading process, which may lead to differences between this version and the Version of Record. Please cite this article as doi: 10.1002/bab.1515.

This article is protected by copyright. All rights reserved. 
PANCMPC: poly[acrylonitrile-co-(2-methacryloyloxyethyl phosphorylcholine)];

PANCHEMA: Poly(acrylonitrile-co-2-hydroxyethyl methacrylate); CB-Cell: Cibacron Blue F3GA bound cellulose; PANCAA: poly(acrylonitrile-co-acrylic acid);

3-aminopropyltriethoxysilane (APTS); 3-chloropropyltriethoxysilane (CPS)

\begin{abstract}
Lipase is one of the most widely used enzymes and plays an important role in biotechnological and industrial processes including food, paper and oleochemical industries as well as in pharmaceutical applications. However, its aqueous solubility and instability make its application relatively difficult and expensive. Immobilization technique is often used to improve lipase performance and the strategy has turned out to be a promising method. Immobilized lipase on nanomaterials (NMs) has shown superiority to the free lipase, such as improved thermal and $\mathrm{pH}$ stability, longer stable time and the capacity of being reused. However, immobilization of lipase on NMs also sometimes causes activity loss and protein loading is relatively lowered under some conditions. The overall performance of immobilized lipase on NMs is influenced by mechanisms of immobilization, type of NMs being used, physicochemical features of the used NMs (such as particle size, aggregation behavior, NM dimension and type of coupling/modifying agents being used). Based on the specific features of lipase and NMs, this review discusses the recent developments, some mechanisms and influence of NMs on lipase immobilization and their activity. Multiple application potential of the immobilized lipases has also been considered.
\end{abstract}


Keywords: Lipase; immobilization; covalent coupling; adsorption; activity retention; protein loading.

\section{Introduction}

Lipases (Triacylglycerol Acyl Hydrolase EC 3.1.1.3) are defined as a class of enzyme that are able to hydrolyze insoluble triacylglycerols at the interface between substrate and water (1). Beside hydrolytic properties, lipases have gained lots of interest in different biocatalytic processes as a result of their capability to catalyze a wide range of reactions (2). Uniquely, when the reaction system contains low water concentrations, they can also catalyze reversed reactions viz. esterification, alcoholysis and acidolysis (3). The versatility of lipases make them one of the most widely used enzymes in commercial utilities, such as textile, detergent, food processing, pulp and paper, fats hydrolysis and modification, oils and oleochemical industry, pharmaceutical processing, resolution of racemic mixtures, chemical analyses as well as biochemistry research (4-6). Lipase is soluble in aqueous solution; hence it will be difficult to separate them from the reaction system. Being a protein molecule, it will be denatured and inactivated under conditions; such as improper $\mathrm{pH}$ and temperature, and the activity of lipase is declined even it is preserved in buffers. For these reasons, free lipase suffers from the difficulty of reusability which impedes the easier and more expansive commercial utilities of lipase. To solve the problems of reuse and stability, immobilization technique has been explored with great success. Different classes of enzymes have been immobilized on different supports, such as synthetic organic polymers, biopolymers, hydrogels and inorganic supports. For the immobilization of lipase, hydrophobic sol-gel (7), polyvinyl chloride, chitosan, chitin, agarose, sepharose, and trisacryl (8), mesoporous silica (9), microporous polymeric matrix have been used (10). It has been found that the immobilized enzymes exhibit higher activity over free ones. Benefits of using enzymes in immobilized forms, as Roger (11) has summarized, include more convenient handling, facile separation, more efficient recovery and reuse, capability of continuous fixed-bed operation 
and often enhanced stability. With larger specific surface area, less diffusion limitation and many other advantages, nanomaterials (NMs) have been used as novel and promising supports for lipase immobilization. In lipase immobilization, nanoparticles (NPs), nanotubes (NTs) and nanofibrous membranes (NFMs) are the most commonly used NMs.

Lipase immobilization on conventional supports or in microemulsion-based organogels and applications of enzymes immobilized on/in NMs in biosensors and biomedical devices have been reviewed before (12-15). However, lipase immobilization on NMs has not been summarized into a written account with conclusive evidence. Considering the unique functions of lipases (both structural and catalytical) and distinction of NMs from other conventional supports, this review gives a more insightful and specific discussion on kinetic behavior, conformational changes, advantages, problems as well as application of immobilized lipases on NMs. Taking NPs, NTs and NFMs as representatives of NMs of different dimensions, possible influential factors, such as particle size or diameter, aggregation behavior, different dimensions, modifier or coupling reagents are discussed in this review.

\section{Kinetic behavior of lipase}

Lipase participates in different reactions such as hydrolysis, esterification, and interesterification. However, according to Paiva et al. a Ping Pong Bi Bi mechanism (Equations 1 and 2) is the most general, accurate, and accepted description for the catalytic action of lipases in all types of catalyzed reactions. This mechanism has two major steps: 1) nucleophilic attack on the ester bond of substrate and 2) hydrolysis of the acylated enzyme complex followed by formation of the product and regeneration of the enzyme (16). In Equations 1 and 2, $\mathrm{A}$ and $\mathrm{B}$ are substrates, $\mathrm{P}$ and $\mathrm{Q}$ are products and $\mathrm{E}$ and $\mathrm{E}^{*}$ are different forms of enzyme.

$$
\begin{aligned}
& \mathrm{E}+\mathrm{A} \leftrightarrow \mathrm{EA} \leftrightarrow \mathrm{E}^{*} \mathrm{P} \leftrightarrow \mathrm{E}^{*}+\mathrm{P} \\
& \mathrm{E}^{*}+\mathrm{B} \leftrightarrow \mathrm{E}^{*} \mathrm{~B} \leftrightarrow \mathrm{EQ} \leftrightarrow \mathrm{E}+\mathrm{Q}
\end{aligned}
$$


In hydrolysis of triglyceride, lipase (E) attacks on ester groups of triglyceride (A) to form glycerol as the first product $(\mathrm{P})$ along with acylated lipase $\left(\mathrm{E}^{*}\right)$ that reacts with water $(\mathrm{B})$ to regenerate lipase and produce fatty acid as the second product $(\mathrm{Q})$.

The general rate expression of Ping-Pong Bi Bi mechanism is shown in Equation 3.

$$
\frac{1}{v}=\frac{K_{m}^{A}}{V_{\max }}\left(\frac{1}{[A]}\right)+\left(1+\frac{K_{m}^{B}}{[B]}\right)\left(\frac{1}{V_{\max }}\right)
$$

Where, $[\mathrm{A}]$ and $[\mathrm{B}]$ are the concentrations of substrate, $\mathrm{K}_{\mathrm{m}}{ }^{\mathrm{A}}$ and $\mathrm{K}_{\mathrm{m}}{ }^{\mathrm{B}}$ are rate constants respect to each substrate and $V_{\max }$ is the maximum rate. It is obvious that when the concentration of one substrate is too high, the Equations 3 simplify to Michaelis-Menten rate expression. In several cases, one of the substrates (for example substrate B) shows an inhibition behavior in high concentrations which appear as an inhibition constant $\left(\mathrm{K}_{\mathrm{I}}\right)$ in the rate expression (Equation 4).

$$
\frac{1}{v}=\frac{K_{m}^{A}}{V_{\max }}\left(\frac{1}{[A]}+\frac{[B]}{[A] K_{I}}\right)+\left(1+\frac{K_{m}^{B}}{[B]}\right)\left(\frac{1}{V_{\max }}\right)
$$

Therefore, for lipase there are several parameters which determine the rate of reaction. In Table 1, the kinetic parameters of lipase in different research studies are summarized. As shown in Table 1, although the $\mathrm{V}_{\max }$ of immobilized lipases on both micro-structured and nano-structured materials falls within a broad range, nanostructured materials generally showed lower $\mathrm{K}_{\mathrm{m}}$ values compared to microstructured ones which is in favor of reaction rate. However, as the used substrates, enzyme source and other conditions are different, this evaluation is not precise.

\section{Conformational control over lipase activity}

Generally, enzymes have different conformational states and their activities and stabilities are different in each state. Lipases have two forms namely "open" and "closed" with equilibrium between them in different media. In aqueous media, there is a tendency to push the 
equilibrium toward the closed form. In this conformation, the active center of enzyme is prevented from exposing to reaction media by a polypeptide chain $(12,17)$. This chain is called lid (or flap) and, in many cases, the closed form of enzyme is fully inactive. In contrast, at a hydrophobic interface such as an oil drop, the lid is opened and the equilibrium is pushed toward the active form. In this case, lipases can be adsorbed as a result of the interaction between hydrophobic surfaces with the internal surface of the lid or the area around the active center as presented in Fig 1. This process is called interfacial activation of lipases and immobilization of the enzyme on hydrophobic supports can help to fix the open form. On the other hand, as shown in Fig 2, lipase molecules tends to form dimeric aggregates through interaction of active centers in their open forms, and therefore enzyme conformation is expected to be less active compared to the monomeric form. In this case, immobilization of enzymes on hydrophobic supports with large surface area results in cleaving these dimers and stabilizing molecules in their open form. As a result, the apparent activity is enhanced due to pushing the equilibrium towards the monomeric open form $(2,12,17-26)$.

The immobilization of lipases on nanostructured supports is a promising gateway for bio-catalysis processes (27). Study of the immobilization mechanisms in nano-scale provides better control on immobilization process. Structural changes in lipase molecule during immobilization on carbon nanotubes (CNTs) have been confirmed by the studies of Feng et al. According to their observation, by measuring the distance between amino acids located at Ile95 of the lid (Thr88-Leu105) and Ile286 of the segment (Asn277-Leu290), the lid opening is enhanced upon the immobilization of the lipase on the hydrophobic CNTs. They found that the salt bridge and hydrogen bonding interactions caused to propagate into the distal region that consequently enhanced lid opening (26). Li et al. functionalized CNTs with cyclodextrin that participated in a specific interaction with hydrophobic amino acids of lipase. It was concluded that the interaction prevented the unfolding of proteins and also refolding proteins from denatured states (28). In another study, Li et al. used carboxyl functionalized graphene oxide for lipase immobilization and concluded that the propagation of hydrophobic interaction between lipase and graphene oxide to the remote regions of lid can induce 
changes in the structure of lipase that consequently caused the lid become more open (29). The stronger hydrophobic interaction at nano-scale level compared to micro-scale level can affect the structure of lipase macromolecules and enhance the opening of lid that consequently improves the catalytic activity and stability.

\section{Lipase immobilization using nanomaterials (NMs)}

From the existing literature, the main mechanisms of lipase immobilization on NMs can be classified as follows:

\subsection{Physical adsorption}

Adsorption is the cheapest and simplest method for immobilization of enzymes on different supports. These processes are performed by direct contact of adsorbent and adsorbate at mild temperature and do not require any chemical compounds. Furthermore, the reversibility of adsorption processes under certain conditions enable the recovery of supports after enzyme deactivation (30). These features reduce the cost of physical immobilizations compared to other methods. Physical adsorption and/or ionic binding are the well-known mechanisms in this technique. The weak attraction forces including van der Waals, hydrogen bonds and hydrophobic interactions between enzyme and support cannot affect the enzyme activity (31). In the case of non-aqueous media, physical adsorption is expected to be promising, since desorption of lipases in organic solvents is negligible (32). Several parameters including ionic strength, isoelectric point, $\mathrm{pH}$ and surface characteristics affect the adsorption of lipases onto carrier materials. The capacity of most supports ranged from 2-50 mg protein per gram (33). Porous supports have more capacity compared to nonporous supports due to their larger surface area. However, their internal morphology should allow accessibility to substrate molecules (34). Usually, lipase follows Langmuir isotherm that means the maximum adsorbed amount is a packed monolayer (35) however Freundlich $(34,36)$ or even the Redlich-Peterson models (37) are suggested by researchers. Adsorption of enzyme is a two steps process, first diffusion to the surface of the adsorbent and then binding at adsorption sites. In case of lipase, since binding is faster than diffusion, adsorption is mainly controlled by diffusion $(36,38-40)$.

This article is protected by copyright. All rights reserved. 
Lipase can be adsorbed on NMs without chemical bonding between lipase and supports. Although, physical adsorption is generally weaker than chemical bonds, it has advantages over other methods on lipase immobilization. Lee et al. used surface-modified nano-sized magnetite (S-NSM) particles as support for porcine pancreas lipase (PPL) immobilization by physical adsorption. NSM particles were made hydrophobic by binding to sodium dodecyl sulfate (SDS) via a sulfate ester bond and then PPL was adsorbed to the NPs. After immobilization, higher specific activity (154.9\%), thermal and alkaline stabilities were detected and the activity of the immobilized PPL remained constant over the subsequent 5 uses and recovery after an initial drop (41). Jiang et al. applied ionic liquids on magnetic NPs for immobilization of high loading of Candida rugosa lipase (CRL) via physical adsorption. Lipase activity in catalyzing esterification of the immobilized ones was 1.07-1.18 times higher than that of free ones and activity remained 92\% after 5 cycles (42). Although advanced activities can be seen in these studies, physical adsorption is only used when the supports are hydrophobic. This phenomenon can be explained by the driving forces for enzyme adsorption at solid-liquid interfaces. Dehydration of hydrophobic interface improves protein adsorption and it may act as the main driving force for enzyme adsorption at solid-liquid interfaces (43). The increased activity of the immobilized lipase is related to the higher affinity between the hydrophobic substrates and the adsorbed lipase (44) as well as structural changes in the enzyme molecule upon adsorption (43).

\subsection{Covalent bonding}

Covalent bonding is the most commonly used method in lipase immobilization on NMs. There are many reports on immobilization using NPs modified with molecules offering active groups which can be bonded to lipase (Fig 3) (40). For studies of lipase immobilization on NPs, the supports have been modified with aldehyde groups (45), succinimidyl ester groups (46) or amino groups (with glutaraldehyde used as a coupling agent) $(47,48)$ to react and bond to the amino groups in lipase, as well as quinone groups (49) that can react with amino or thiol groups of lipase. Because of the formation of chemical bonds (many of which are peptide bonds), the stability of the immobilized lipase can be achieved through washing and increased recyclability. Another advantage of covalent coupling method is the enhanced 
function of lipase. Most of the studies observed wider $\mathrm{pH}$ range and higher thermal stability (45,47-49), and long lasting activity (46). Also, the large specific area of NPs provides possibility of holding more lipase molecules on one particle. However, declined activity is often observed after covalent bonding immobilization. This phenomenon is used to explain the rigidity and formation of lipase. However, conformation change does not always have negative influence on lipase activities during the immobilization (40,50-53). Feng et al. (26) conducted experiments to clarify the mechanism of immobilized lipase lid opening, which is considered to be the main reason for activity enhancement. In the experiment, they compared the conformation of lipase immobilized in cross-linking system, lipase immobilized by adsorption and free lipase. It was concluded that the lid opens upon the lipase immobilization on the CNTs. Furthermore, the complexity of this method is another limitation. To load reactive groups on NPs, researchers frequently follow sophisticated protocols, which consume time and are expensive.

\section{Different NMs used in lipase immobilization}

There are different NMs such as NPs, NTs and NFMs, that have been used for immobilization of lipases. Below are discussed the studies with promising results.

\subsection{Nanoparticles (NPs)}

NPs are the most important NMs with multiple applications in bioprocesses. Different NPs have been used in lipase immobilization (Table 2). In the last decade, NPs have been used for lipase immobilization for obtaining higher activity, recovery and better reusability. After observing some of the traditional NPs, such as metals and $\mathrm{SiO}_{2}$, researchers paid more attention to magnetic NPs, which possessed advantages over the non-magnetic NPs. Besides higher specific area and low mass resistance, magnetic NPs also provided: 1) easier separation from reaction system; 2) ability to be stabilized on desired sites in the reaction system; and 3) lower cost because of the reusability of the support and easy operational process. However, magnetic NPs cannot be applied directly as it diminish the superiority of lipase.

This article is protected by copyright. All rights reserved. 
Huang et al. reported enhanced activity and higher efficiency of the immobilized lipase after direct binding to magnetic NPs provided that weight ratio of lipase bound to $\mathrm{Fe}_{3} \mathrm{O}_{4}$ NPs were below 0.033 . This meant a lower lipase loading on magnetic material is the pre-requisite for enhanced activity of the immobilized lipase. Apart from this limitation, magnetic NPs are more susceptible to easy aggregation that lowers the specific area for lipase immobilization. For a better adaptability of lipase on magnetic NMs, further investigations were made on method development for modifying magnetic NPs with different chemicals to either form a hydrophobic surface for adsorption or provide functional groups for covalent coupling. These surface modified magnetic NPs carry the advantages of both nano-dimension and magnetic property and provide affinity to lipase because of the hydrophobic surface or active groups. The values of $\mathrm{V}_{\max }$ and $\mathrm{K}_{\mathrm{m}}$ for bound lipase were 1.4 and 3.75 times higher and lower than those for free lipase respectively (54). Some of the studies showed less aggregation after surface modification, which is a desirable effect However, Lee et al. reported increased particle aggregation after lipase immobilization (41), and Ren et al. also observed agglomerates after surface modification with polydopamine (49). In a recent work, Meng et al used $\mathrm{Fe}_{3} \mathrm{O}_{4}$ NPs for immobilization of lipase obtained from Mucor javanicus. They bounded lipase covalently to surface of activated magnetite NPs and later cross-linked to form enzyme aggregates. The immobilized showed only $10 \%$ loss of activity after 10 cycle of producing 1, 3-diacylglycerols at $55{ }^{\circ} \mathrm{C}$ (55). Shao et al immobilized lipase on three mesoporous magnetic NPs and optimized the immobilization conditions. These three NPs were obtained by coating $\mathrm{Fe}_{3} \mathrm{O}_{4}$ NPs with mesoporous silica and grafting by both 3-aminopropyltriethoxysilane (APTS) and 3-chloropropyltriethoxysilane (CPS). The enzyme was immobilized onto three NPs through covalent bonding, physical adsorption and cross-linking. Their results indicated that NPs grafted with CPS was the best candidate for lipase immobilization, showing $96 \%$ immobilization efficiency and high stability (83\% after 56 days) and reusability ( $86.7 \%$ ten cycles) with covalent boding method (56).

\subsection{Nanotubes (NTs)}


The last decade witnessed the explosion of NTs studies. They are favored as a kind of versatile nanomaterial with many desirable functions. On one hand, NTs have diameter in nanoscale, which means they enjoy the advantage of high specific area. On the other hand, their intrinsic length gives them the capacity to be filtered, which is considered as a mild and simple way of recovery. Both multi-walled and single-walled carbon and non-carbon NTs have been used in lipase immobilization. A summary of the different NTs used in lipase immobilization and their performance is presented in Table 3.

\section{(a) Multi-walled carbon nanotubes (MWCNTs)}

Asuri et al. prepared water-soluble conjugates of CNTs with large range of enzymes including lipase which were first oxidized and then N-hydroxysuccinimide (NHS) was coupled to NTs for activation. After immobilization, $58 \pm 7 \%$ higher stability was observed for Candida antarctica Lipase B.(57). In a related work, Ji et al. carried out similar lipase immobilization onto MWCNTs and about $76-82 \%$ of the activity was retained (58). Another experiment under non-aqueous condition was conducted by Shah et al., in which CRL was immobilized on MWCNTs by adsorption and the activity recovery was as high as 97\% (59). Prlainovic et al. immobilized CRL onto unmodified MWCNTs and obtained $85 \%$ of initial activity. According to their results, highest retention of lipase activity obtained at the lowest initial enzyme concentration and high ionic strength that is due to interactions that activated the lipase during the immobilization process (60). Amino-cyclodextrin functionalized MWCNTs were used in lipase adsorption and higher activity was obtained with well-preserved secondary structure of lipase (61). Verma et al. bonded lipase covalently onto amino functionalized MWCNTs supports using a glutaraldehyde cross-linker. In this study, the immobilized lipase activity obtained was $114 \%$ of free lipase and $50 \%$ of the activity was maintained after 10 cycles of catalysis (62). In another study, Raghavendra et al. covalently immobilized lipase by two methods onto MWCNTs. In one method, they employed carbodiimide chemistry and in the other, they used (3-Aminopropyl) triethoxysilane (APTES) as cross linker followed by succinic acid anhydride (SAA) treatment. According to their observations, after 50 cycles, the immobilized enzyme using carbodiimide exhibited 
$\sim 79 \%$ activity for the immobilized enzyme using APTES and SAA retained $\sim 30 \%$ activity (2). Tan et al. combined magnetic NPs with multi-walled carbon nanotubes to form magnetic nanotubes; and the lipase immobilized on M-MWCNTs retained about $83 \%$ of its activity (63).

\section{(b) Single-walled carbon nanotubes (SWCNTs)}

Lee et al. immobilized lipase from Pseudomonas cepacia onto 1-pyrenebutyric acid N-hydroxysuccinimide (NHS) ester functionalized SWCNTs in different solvent systems (buffer and ionic liquid) by covalent coupling. The results showed the superiority of ionic liquid in this process by giving much higher lipase activity (64). Ghosh et al. used reverse micellar functionalized single-walled carbon nanotubes for lipase immobilization, and lipase activity increased from 1.1 to 2.5 fold under different conditions. They attributed the improved activity of lipase to its smooth occupancy and also the increased concentrations of substrate and enzyme at the interface (65).

\section{(c) Non-carbon nanotubes}

Apart from carbon nanotubes, nanotubes of other materials have also been investigated in the recent years. In the study of Dhand et al. polyaniline nanotubes were used as lipase support, and the immobilization was acquired by using glutaraldehyde (66). In another study by Bai et al., mesoporous silica nanotubes (MSNTs) and aminopropyl-grafted mesoporous silica nanotubes $\left(\mathrm{NH}_{2}\right.$-MSNTs) were used by for lipase immobilization by means of adsorption. The lipase immobilized on $\mathrm{NH}_{2}$-MSNTs showed twice hydrolization activity compared to MSNTs (67).

\subsection{Nanofibrous membranes (NFMs)}

NFMs are also commonly used in lipase immobilization. Some of the recent research findings on this topic are presented in Table 4. Although most of the diameters of NFMs mentioned in lipase immobilization are not in nanoscale $(<100 \mathrm{~nm})$, they have nanoscale pore sizes which affected the activity retention of immobilized lipase. However, most research reported the diameter of NFMs material rather than pore size. As it can be seen from Table 4, different 
materials of the NFMs influence the properties of immobilized lipase. However, different modifiers or pretreatment (activated or not) of same basic material have lower effect on activity retention than on protein loading. From the existing reports, lipases immobilized on PAN (including activated PAN) NFMs have higher reusability, which is an important factor that influences the application of immobilized lipase.

\section{Factors that influence lipase immobilization on/in nanomaterials (NMs)}

For better application of lipases in large-scale, higher activity retention, better stability and more reusability are desired. By immobilizing of lipase on NMs, most of the studies reported stability in wider range of temperature and $\mathrm{pH}$ changes. However, some significant factors, namely activity retention and protein loading, showed different characteristics in various studies. In other words, the effects of immobilization of lipase on NMs need more insightful discussion. Below are discussed the some of the important features of NMs that influence the performance of immobilized lipases.

\subsection{Particle size}

Particle size of NMs has profound influence on the performance of immobilized lipase. Researchers modified the scale of enzyme supports form micro to nano for the sake of superior functions of smaller particle size, such as higher surface to volume ratio, lower mass transfer resistance, lower diffusion resistance and some special surface effect. These advantages of small particles are beneficial for better performance of enzymes and especially for lipase as it catalyzes at the interface of substrate and water (68). For this reason, lipase immobilized on NMs with smaller particle size or diameter should have better activity retention. However, studies showed that the particle size may not follow "the smaller the better" rule in the case of lipase immobilization. Too large surface area may not be a positive parameter, as lipase tends to maximize its contact with the surface (69). Lipase may change conformation to achieve maximum contact with the surface, thus the activity of immobilized lipase can be damaged by this action. Contrarily, very small particle size may cause difficulty in contact with interface when lipase is immobilized on the surface of NPs. When the diameter of NP decreases, the radius between two adjacent lipases will increase (provided 
that lipase spreads evenly on the support surface). It will be more difficult for adjacent lipases to come in contact with substrate, which can affect the activity recovery of immobilized lipase. In the study of lipase immobilization on mesoporous NPs SBA-15 (Santa Barbara Amorphous-15) by adsorption, effect of pore diameter $(6.8 \mathrm{~nm}, 9.1 \mathrm{~nm}, 13.2 \mathrm{~nm}, 15.6 \mathrm{~nm}$ and $22.4 \mathrm{~nm}$ ) was observed (70). The results showed that the lipase adsorption capacity on the NMs followed the order: $15.6 \mathrm{~nm}>13.2 \mathrm{~nm}>9.1 \mathrm{~nm}$ and the lipase activity on $9.1 \mathrm{~nm}$ were lower than that of 13.2 and $15.6 \mathrm{~nm}$. This indicated that too small diameter may not be a positive factor in case of nanoporous based immobilization of lipase.

\subsection{Aggregation behavior}

Because of the unique properties (such as small particle size, surface and interface effects) of NMs, they are more prone to aggregation (71). Besides magnetic NPs, aggregation behavior is also reported for chitosan NPs, confirming that aggregation is not distinctive property of magnetic NPs (72). Aggregation of the supporting materials can also affect the overall performance of immobilized lipase. However, the effect of lipase aggregate upon immobilization has not been clearly understood. It is reported that in organic solvents, enzyme forms aggregates that diminish their access to substrates, thus negatively affecting the activity. Hence, dispersion of lipase on NMs is considered as a desirable criterion for not forming aggregates $(59,64)$. Contrarily, as reported by Kim et al., the activity of enzyme-aggregate-coated NFs was found to be nine times higher than that of the NFs with just a layer of covalently attached enzyme, (73). Similarly, in the study of immobilizing lipase on PAN NFMs (74), the first layer of bounded lipase acted as seeds and then other lipase could be absorbed by lipase-lipase interaction, which could be seen as a positive effect on lipase loading.

A possible explanation can be the effect of different solvents on aggregation mechanisms of lipase. In the presence of an organic solvent, lipase may tend to form aggregates with their active center inside, while in aqueous solvents they are more likely to aggregate with the exposed active center, which positively affected the overall performance of immobilized lipase. According to Torres et al. aggregation of suspended lipase in organic solvent 
(acetonitrile) can protect them from conformational changes and it means that enzyme in inactive conformation is more stable (75).

\subsection{Different modifiers/coupling reagents}

To obtain more desirable effects, most of the studies used some modifiers or coupling reagents upon immobilizing lipase on NMs. These reagents are used for different purposes such as disaggregation of magnetic NPs (42), to provide active groups that can covalently bind to lipase and or hydrophobic surface to adsorb lipase $(41,76)$. Modifiers or coupling reagents act differently upon the change of immobilization mechanisms and have profound influence on lipase immobilization. From the existing results (Table 4), it can be seen that different modifiers have no significant influence on lipase loading (77-79), while the activity retention fluctuated with the change of modifiers. One possible explanation for the relatively stable protein loading could be the immobilization mechanism. In the case of covalent coupling, the factor influencing protein loading is the number of functional groups on the supports, rather than the type of the groups. For the activity retention, there are more other factors that may influence it at the same time. As proposed by Raghavendra et al. modifiers offered distance between lipase and the support (acting as spacer arm) may provide more flexibility for lipase, hence increasing their activity. The spacer arm may also be vulnerable to breakage by shearing and thus leading to decrease in reusability. Thus, choosing suitable modifier is crucial for lipase immobilization (2).

\section{Advantages and disadvantages of the nano-immobilized lipases}

The general advantages and disadvantages of using nanostructured support for immobilization of enzyme are summarized in Table 5. Generally, immobilization of the enzyme can overcome the drawbacks of free enzymes such as lack of long-term operational stability and difficult recovery (12,81-83). Recently, in order to increase the performance of immobilized enzyme, researchers have focused on nanostructured supports due to their main advantage i.e. large surface area. This characteristic led in higher loading of enzyme and subsequently biocatalytic activity per unit mass was remarkably increased. For example, 
Tudorache et al. observed that the optimum enzyme loading of functionalized magnetic NPs with the diameter of $50 \mathrm{~nm}(3.1 \mu \mathrm{g}$ enzyme/mg support) was up to 20 times more than that of micro-particles with the diameter of $500 \mathrm{~nm}(0.15 \mu \mathrm{g}$ enzyme/mg support) (84). Furthermore, nanobiocatalysts showed excellent chemical and mechanical stability during bioconversion processes compared to the conventional immobilized enzyme that is a key factor in process design $(82,85,86)$. As an instance, Dyal et al. showed that immobilized lipase onto magnetic NPs was stable up to one month compared to less than one day for free and five days for immobilized enzyme on silica gels $(87,88)$. Moreover, materials with adsorption capability such as chitosan or hydrophobic nature such as clay, showed faster equilibrium and much more adsorption capacity in their nanoscale form compared to their macroscale ones which played a key role in high accessibility of the substrate and the product $(85,89)$. Such a remarkable improvement in the enzyme loading and stability can result in faster reaction, higher yield, smaller reactor, lower enzyme consumption and more feasible separation in the case of magnetic nanoparticles. However, for commercialization of nanobiocatalysts, challenges such as high fabrication cost, entrapment of enzyme into pores of nanoporous materials and separation of non-magnetic nanoparticles from reaction medium should be addressed.

\section{Applications}

On account of the versatility, the application of lipase is extensive. Immobilization of lipase paved the way for more widespread and larger scale application of lipase, including industrial and medical fields. In recent years, lipase immobilization on NMs has shown promising benefits for wider usage in multiple aspects. Lipases are generally used in the processing of fats, food, leather, textile, detergents, paper and also synthesis of fine chemicals, pharmaceuticals and cosmetics $(4,90)$. Furthermore, lipase has the capability to accelerate the degradation of fatty waste (91) and polyurethane (92).

This article is protected by copyright. All rights reserved. 


\subsection{Oil hydrolysis}

Hydrolysis is one of the important applications of lipase, but lower stability and higher cost impede the application at large scale. Immobilization of lipase on nanoparticles can be a solution to this problem. $\mathrm{Li}$ and $\mathrm{Wu}$ (74) studied lipase immobilization on polyacrylonitrile (PAN) nanofibrous membranes and used it in soybean oil hydrolysis. They found that in the reaction system, hydrolysis conversion of soybean oil was $72 \%$ after 10 min and $85 \%$ after $1.5 \mathrm{~h}$, and immobilized lipase was able to retain $65 \%$ of its original conversion after 20 cycles of reuse.

\subsection{Organic synthesis}

Using lipases in chemical synthesis of organic materials is becoming increasingly important because lipases showed capability in catalyzing wide variety of chemo-, regio-, and stereoselective reactions (93). For example, Silva and Jesus studied the synthesis of esters by reaction of hexanoic, octanoic and lauric acid with methanol, ethanol, 1-butanol and 1-octanol in organic solvent in the presence of different lipases immobilized on chrysotile. Under the best applied conditions, they obtained ester with yields between 62\% (methyl laurate) and 97\% (n-butyl laurate) (94). The reaction between n-butanol and lauric acid is shown in Reaction 1.

It has been reported that lipase immobilized on amino-functionalized magnetic nanoparticles can be used in diltiazem (a calcium channel blocker) intermediate synthesis, with $59.6 \%$ of its activity being retained after 11 consecutive cycles of usage (95). This meant that immobilized lipase on NMs may also be useful in synthesis of organic compounds such as pharmaceuticals. In pharmaceutical synthesis, enzymatic route has advantages over chemical one including mild conditions that avoid reactions such as racemization, epimerization, isomerization and rearrangement. Specifically, lipase's capability to resolve racemic mixtures through the synthesis of a single enantiomer is currently deployed for production of several pharmaceutical compounds $(4,5,93)$ and researchers are working on using lipase for other compounds. For example, Bai et al. used immobilized lipase on lauric acid-stabilized magnetic nanoparticles for the resolution of racemic menthol. This goal was achieved by

This article is protected by copyright. All rights reserved. 
enantioselective esterification of with propionic anhydride that resulted in (-)-menthyl propionate with a yield higher than $96 \%$ (96). In a similar study, Zhang et al. used Candida antarctica (Novozyme $^{(\mathrm{R})}$ 435) lipase for the racemic resolution of flurbiprofen through enantioselective esterification with alcohols and in small scale-up reaction system they achieved $91 \%$ ee and $67 \%$ total conversion (97). The racemic resolution of primary alcohols by Pseudomonas cepacia (PS) lipase (98) is shown in Reaction 2.

In a recent study by Haritha et al., lipase immobilized on magnetic nanoparticles was used for the synthesis of disulphide compounds. The immobilized lipase hydrolyzed the aromatic and aliphatic thiol acetates into the respective disulphide compounds. The enzymatic hydrolysis process did not generate intermediates products and disulphide compounds were spontaneously formed by thiol radicals under the maintained anaerobic conditions (99). In another recent study, lipases from Pseudomonas fluorescens were immobilized on MWCNTs that catalyzed O-acylation reactions (100). The immobilized lipases showed 2.3 folds higher catalytic activity than free lipases and recycling ability was 5 cycles.

\subsection{Biodiesel production}

Immobilized lipase application in biodiesel production has been observed by many researchers, including conversion of soybean oil to biodiesel fuel $(101,102)$, production of biodiesel fuel from triglycerides and alcohol (103), and biodiesel production from waste cooking oil (10). Xie and Ma (53) used lipase immobilized on magnetic nanoparticles in transesterification of soybean oil, and conversion of soybean oil to methyl esters reached over 90\% when $40 \%$ immobilized lipase was used with higher thermal stability and acceptable reusability. Li et al. (104) obtained conversion as high as $91 \%$ of the original data obtained after ten cycles, which provided a promising method for biodiesel synthesis using lipase immobilized on NMs. Packed bed reactor (PBR) used by Wang et al. (105) showed prospects in reactor scale biodiesel synthesis. Both single-PBR and four-PBR system were built and well-studied, and the conversion of the systems was $75 \%$ and $88 \%$, respectively. With the success of the reactor scale system, it is expected that immobilized lipase on NMs could be utilized in larger scale biodiesel production. 


\section{Conclusions}

Lipase is usually immobilized by mechanisms of adsorption and covalent coupling, while entrapment is rarely used because of the need of contact between lipase active center and the interface. Different kinds of nanoparticles, nanotubes and nanofibrous membranes are used in lipase immobilization. Because of the difference in nano-dimension, these nanomaterials may have distinct influence on the performance of immobilized lipase. Other influential factors, such as particle size or diameter, aggregation behaviors of both lipase and nanomaterials and different reagents used in immobilization process were highlighted and discussed. With desirable functions, lipase immobilized on nanomaterials possesses multiple application potential, including biosensor, oil hydrolysis, pharmaceutical synthesis and biodiesel production. With the accumulation of knowledge of lipase immobilization on nanomaterials, more controllable, specific systems designed for higher efficacy utilization of lipase is expected. However there are several challenges in using nanomaterials including high production cost, aggregation potential, non-uniformity and lack of knowledge on immobilized enzyme aggregates. Therefore, to obtain enhanced utility of lipase and to be competitive with freely available conventional supports, choosing suitable supports and reagents and also overcoming the related challenges is essential.

\section{Acknowledgements}

Financial support of the Natural Sciences and Engineering Research Council of Canada (Discovery Grant 355254), MAPAQ (No. 809051) and Ministère des Relations Internationales du Québec (coopération Paraná-Québec 2010-2012; cooperation Québec -Vietnam) is sincerely acknowledged. Support of MITACs Globalinks programme to Ms. Weitao Shuai for completing this research is acknowledged. FQRNT merit scholarship program for foreign student (MELS) is also acknowledged for financial assistance to Mr. Ratul Kumar Das

\section{Conflict of interest}

The authors declare that there are no conflicts of interest. 


\section{References}

[1] Silva, W. O. B., Mitidieri, S., Schrank, A., Vainstein, M. H., (2005) Process Biochem. 40, 321-326.

[2] Raghavendra, T., Basak, A., Manocha, L. M., Shah, A. R., Madamwar, D., (2013) Bioresour. Technol. 140, 103-110.

[3] Gupta, R., Gupta, N., Rathi, P., (2004) Appl. Microbiol. Biotechnol. 64, 763-781.

[4] Singh, A. K., Mukhopadhyay, M., (2012) Appl. Biochem. Biotechnol. 166, 486-520.

[5] Hasan, F., Shah, A. A., Hameed, A., (2006) Enzyme Microb. Technol. 39, 235-251.

[6] Sharma, R., Chisti, Y., Banerjee, U. C., (2001) Biotechnol. Adv. 19, 627-662.

[7] Reetz, M. T., Zonta, A., Simpelkamp, J., (1996) Biotechnol. Bioeng. 49, 527-534.

[8] Shaw, J. F., Chang, R. C., Wang, F. F., Wang, Y. J., (1990) Biotechnol. Bioeng. 35, $132-137$.

[9] Blanco, R. M., Terreros, P., Fernández-Pérez, M., Otero, C., Díaz-González, G., (2004) J. Mol. Catal. B: Enzym. 30, 83-93.

[10] Dizge, N., Aydiner, C., Imer, D. Y., Bayramoglu, M., Tanriseven, A., Keskinler, B., (2009) Bioresour. Technol. 100, 1983-1991.

[11] Roger, A. S., (2007) Adv. Synth. Catal. 349, 1289-1307.

[12] Mateo, C., Palomo, J. M., Fernandez-Lorente, G., Guisan, J. M., Fernandez-Lafuente, R., (2007) Enzyme Microb. Technol. 40, 1451-1463.

[13] Zoumpanioti, M., Stamatis, H., Xenakis, A., (2010) Biotechnol. Adv. 28, 395-406. 
[14] Ansari, S. A., Husain, Q., (2012) Biotechnol. Adv. 30, 512-523.

[15] Pavlidis, I. V., Patila, M., Bornscheuer, U. T., Gournis, D., Stamatis, H., (2014) Trends Biotechnol. 32, 312-320.

[16] Paiva, A. L., Balcão, V. M., Malcata, F. X., (2000) Enzyme Microb. Technol. 27, 187-204.

[17] Hernandez, K., Fernandez-Lafuente, R., (2011) Enzyme Microb. Technol. 48, 107-122.

[18] Brzozowski, A. M., Savage, H., Verma, C. S., Turkenburg, J. P., Lawson, D. M., Svendsen, A., Patkar, S., (2000) Biochemistry. 39, 15071-15082.

[19] Fernandez-Lafuente, R., Armise'n, P., Sabuquillo, P., Ferna'ndez-Lorente, G., Guisa'n, J. M., (1998) Chem. Phys. Lipids. 93, 185-197.

[20] Garcia-Galan, C., Berenguer-Murcia, A., Fernandez-Lafuente, R., Rodrigues, R. C., (2011) Adv. Synth. Catal. 353, 2885-2904.

[21] Rodrigues, R. C., Ortiz, C., Berenguer-Murcia, Á., Torres, R., Fernández-Lafuente, R., (2013) Chem. Soc. Rev. 42, 6290-6307.

[22] Gonza'lez-Navarro, H., Carmen Baño', M., Abad, C., (2001) Biochemistry. 40, 3174-3183.

[23] Carrasco-Lo’́pez, C., Godoy, C., de las Rivas, B., Ferna’ndez-Lorente, G., Palomo, J. M., Guisa'n, J. M., Ferna'ndez-Lafuente, R., Martı'nez-Ripoll, M., Hermoso, J. A., (2009) J. Biol. Chem. 284, 4365-4372.

[24] Arpigny, J., Jaeger, K., (1999) Biochem. J. 343, 177-183. 
[25] Brzozowski, A. M., Derewenda, U., Derewenda, Z. S., Dodson, G. G., Lawson, D. M., Turkenburg, J. P., Thim, L., (1991) Nature. 351, 491-494.

[26] Feng, W., Sun, X., Ji, P., (2012) Soft Matter. 8, 7143-7150.

[27] Brígida, A. I. S., Amaral, P. F. F., Coelho, M. A. Z., Gonçalves, L. R. B., (2014) J. Mol. Catal. B: Enzym. 101, 148-158.

[28] Li, L., Feng, W., Pan, K., (2013) Colloids Surf. B. Biointerfaces. 102, 124-129.

[29] Li, Q., Fan, F., Wang, Y., Feng, W., Ji, P., (2013) Ind. Eng. Chem. Res. 52, 6343-6348.

[30] Deng, H.-T., Xu, Z.-K., Liu, Z.-M., Wu, J., Ye, P., (2004) Enzyme Microb. Technol. 35, 437-443.

[31] Andrade, J. D., Hlady, V., (1986) Adv. Polym. Sci. 79, 1-63.

[32] Knežević, Z., Mojović, L., Adnadević, B., (1998) J. Serb. Chem. Soc. 63, 257-264.

[33] Villeneuve, P., Muderhwa, J. M., Graille, J., Haas, M. J., (2000) J. Mol. Catal. B: Enzym. 9, 113-148.

[34] Mojović, L., Knežević, Z., Jovanović, S., (1999) Appl. Microbiol. Biotechnol. 50, 676-681.

[35] Malcata, F. H., Reyes, H. R., Garcia, H. S., Hill, C. G., Amundson, C. H., (1990) J. Am. Oil Chem. Soc. 67, 890-910.

[36] Knežević, Z., Mojović, L., Adnadjević, B., (1998) Enzyme Microb. Technol. 22, 275-280.

[37] Duri, B. A., Yong, Y. P., (2000) Biochem. Eng. J. 4, 207-215. 
[38] Palomo, J. M., Munoz, G., Fernandez-Lorente, G., Mateo, C., Fernandez-Lafuente, R., Guisan, J. M., (2002) J. Mol. Catal. B: Enzym. 19-20, 279-286.

[39] Mojović, L., Šiler-Marinković, S., Kukić, G., Vunjak-Novaković, G., (1993) Enzyme Microb. Technol. 15, 438-443.

[40] Knezevic, Z. D., Siler-Marinkovic, S. S., Mojovic, L. V., (2004) Acta periodica technologica, 151-164.

[41] Lee, D. G., Ponvel, K. M., Kim, M., Hwang, S., Ahn, I. S., Lee, C. H., (2009) J. Mol. Catal. B: Enzym. 57, 62-66.

[42] Jiang, Y., Guo, C., Xia, H., Mahmood, I., Liu, C., Liu, H., (2009) J. Mol. Catal. B: Enzym. 58, 103-109.

[43] Duinhoven, S., Poort, R., Van der Voet, G., Agterof, W. G. M., Norde, W., Lyklema, J., (1995) J. Colloid Interface Sci. 170, 340-350.

[44] Santos, J. C., Bueno, T., Molgero, P. C., Rós, D., De Castro, H. F., (2007) J. Chem. Technol. Biotechnol. 82, 956-961.

[45] Bai, Y. X., Li, Y. F., Yang, Y., Yi, L. X., (2006) Process Biochem. 41, 770-777.

[46] Drechsler, U., Fisher, N. O., Frankamp, B. L., Rotello, V. M., (2004) Adv. Mater. 16, 271-274.

[47] Xie, W., Ma, N., (2009) Energy Fuels. 23, 1347-1353.

[48] Cui, Y. J., Li, Y. F., Yang, Y., Liu, X., Lei, L., Zhou, L., Pan, F., (2010) J. Biotechnol. 150, $171-174$. 
[49] Ren, Y., Rivera, J. G., He, L., Kulkami, H., Lee, D. K., Messersmith, P. B., (2011) BMC Biotechnol. 11 : 63.

[50] Rodrigues, A. R., Cabral, J. M. S., Taipa, M. A., (2002) Enzyme Microb. Technol. 31, $133-141$.

[51] Adamczak, M., Bednarski, W., (2004) Process Biochem. 39, 1347-1361.

[52] Arroyo, M., Moreno, J. M., Sinisterra, J. V., (1999) Enzyme Microb. Technol. 24, 3-12.

[53] Xie, W., Ma, N., (2010) Biomass Bioenergy. 34, 890-896.

[54] Huang, S. H., Liao, M. H., Chen, D. H., (2003) Biotechnol. Prog. 19, 1095-1100.

[55] Meng, X., Xu, G., Zhou, Q.-L., Wu, J.-P., Yang, L.-R., (2014) Food Chem. 143, 319-324.

[56] Shao, Y.-B., Jing, T., Tian, J.-Z., Zheng, Y.-J., Shang, M.-H., (2015) Chemical Papers. 69, 1298-1311.

[57] Asuri, P., Karajanagi, S. S., Sellitto, E., Kim, D. Y., Kane, R. S., Dordick, J. S., (2006) Biotechnol. Bioeng. 95, 804-811.

[58] Ji, P., Tan, H., Xu, X., Feng, W., (2010) AICHE J. 56, 3005-3011.

[59] Shah, S., Solanki, K., Gupta, M. N., (2007) Chem. Cent. J. 1, 1-6.

[60] Prlainović, N. Ž., Bezbradica, D. I., Knežević-Jugović, Z. D., Stevanović, S. I., Avramov Ivić, M. L., Uskoković, P. S., Mijin, D. Ž., (2013) Ind. Eng. Chem. 19, 279-285.

[61] Li, L., Feng, W., Pan, K., (2013) Colloids Surf. B. Biointerfaces. 102, 124-129. 
[62] Verma, M. L., Naebe, M., Barrow, C. J., Puri, M., (2013) PLOS One. 8, 1-9.

[63] Tan, H., Feng, W., Ji, P., (2012) Bioresour. Technol. 115, 172-176.

[64] Lee, H. K., Lee, J. K., Kim, M. J., Lee, C. J., (2010) Bull. Korean Chem. Soc. 31, $650-652$.

[65] Ghosh, M., Maiti, S., Dutta, S., Das, D., Das, P. K., (2012) Langmuir. 28, 1715-1724.

[66] Dhand, C., Solanki, P. R., Sood, K. N., Datta, M., Malhotra, B. D., (2009) Electrochem. Commun. 11, 1482-1486.

[67] Bai, W., Yang, Y. J., Tao, X., Chen, J. F., Tan, T. W., (2012) J. Mol. Catal. B: Enzym. 76, $82-88$.

[68] Lopes, D., Fraga, L. P., Fleuri, L. F., Macedo, G. A., (2011) Food Sci. Technol. 31, 603-613.

[69] Bosley, J. A., Peilow, A. D., in: M. N. Gupta (Ed), Methods in Non-Aqueous Enzymology, Birkhäuser Basel, Basel 2000, pp. 52-69.

[70] Gao, S., Wang, Y., Diao, X., Luo, G., Dai, Y., (2010) Bioresour. Technol. 101, 3830-3837.

[71] Tang, Z. X., Qian, J. Q., Shi, L. E., (2007) Mater. Lett. 61, 37-40.

[72] Wu, Y., Wang, Y., Luo, G., Dai, Y., (2009) Bioresour. Technol. 100, 3459-3464.

[73] Kim, B. C., Nair, S., Kim, J., Kwak, J. H., Grate, J. W., Kim, S. H., Gu, M. B., (2005) Nanotechnology. 16, 382-388.

[74] Li, S. F., Wu, W. T., (2009) Biochem. Eng. J. 45, 48-53. 
[75] Torres, C., Otero, C., (1995) J. Mol. Catal. A: Chem. 97, 119-134.

[76] Mahmood, I., Guo, C., Xia, H., Ma, J., Jiang, Y., Liu, H., (2008) Ind. Eng. Chem. Res. 47, 6379-6385.

[77] Ye, P., Xu, Z. K., Wu, J., Innocent, C., Seta, P., (2006) Biomaterials. 27, 4169-4176.

[78] Huang, X. J., Yu, A. G., Xu, Z. K., (2008) Bioresour. Technol. 99, 5459-5465.

[79] Huang, X. J., Yu, A. G., Jiang, J., Pan, C., Qian, J. W., Xu, Z. K., (2009) J. Mol. Catal. B: Enzym. 57, 250-256.

[80] Zhao, D., Peng, C., Zhou, J., (2015) PCCP. 17, 840-850.

[81] Sheldon, R. A., Pelt, S. v., (2013) Chem. Soc. Rev. 42, 6223-6235.

[82] Cipolatti, E. P., Silva, M. J. A., Klein, M., Feddern, V., Feltes, M. M. C., Oliveira, J. V., Ninow, J. L., de Oliveira, D., (2014) J. Mol. Catal. B. Enzym. 99, 56-67.

[83] Ahmad, R., Sardar, M., (2015) Biochem \& Anal Biochem. 4, 1-8.

[84] Tudorache, M., Protesescu, L., Negoi, A., Parvulescu, V. I., (2012) Applied Catalysis A: General. 437-438, 90-95.

[85] Min, K., Yoo, Y., (2014) Biotechnol Bioproc E. 19, 553-567.

[86] Asgher, M., Shahid, M., Kamal, S., Iqbal, H. M. N., (2014) J. Mol. Catal. B: Enzym. 101, 56-66.

[87] Dyal, A., Loos, K., Noto, M., Chang, S. W., Spagnoli, C., Shafi, K. V. P. M., Ulman, A., Cowman, M., Gross, R. A., (2003) J. Am. Chem. Soc. 125, 1684-1685. 
[88] Hwang, S., Lee, K.-T., Park, J.-W., Min, B.-R., Haam, S., Ahn, I.-S., Jung, J.-K., (2004) Biochem. Eng. J. 17, 85-90.

[89] Wu, Y., Wang, Y., Luo, G., Dai, Y., (2009) Bioresour. Technol. 100, 3459-3464.

[90] Houde, A., Kademi, A., Leblanc, D., (2004) Appl. Biochem. Biotechnol. 118, 155-170.

[91] Masse, L., Kennedy, K. J., Chou, S., (2001) Bioresour. Technol. 77, 145-155.

[92] Takamoto, T., Shirasaka, H., Uyama, H., Kobayashi, S., (2001) Chem. Lett. 30, 492-493.

[93] Jaeger, K.-E., Reetz, M. T., Trends Biotechnol. 16, 396-403.

[94] Silva, J. E. S., Jesus, P. C., (2003) An. Acad. Bras. Ciênc. 75, 157-162.

[95] Hu, B., Pan, J., Yu, H. L., Liu, J. W., Xu, J. H., (2009) Process Biochem. 44, 1019-1024.

[96] Bai, S., Guo, Z., Liu, W., Sun, Y., (2006) Food Chem. 96, 1-7.

[97] Zhang, H. Y., Wang, X., Ching, C. B., Wu, J. C., (2005) Biotechnol. Appl. Biochem. 42, $67-71$.

[98] Luna, A., Maestro, A., Astorga, C., Gotor, V., (1999) Tetrahedron: Asymmetry. 10, 1969-1977.

[99] Haritha, V., Mitaram, H., Rao, A.B., (2015) Green Sus. Chem. 5, 25-30.

[100] Badgujar, K.C., Sasaki, T., Bhanage, B.M., (2015) RSC Adv. 5, 55328-55251

[101] Watanabe, Y., Shimada, Y., Sugihara, A., Tominaga, Y., (2002) J. Mol. Catal. B: Enzym. 17, 151-155. 
[102] Noureddini, H., Gao, X., Philkana, R. S., (2005) Bioresour. Technol. 96, 769-777.

[103] Iso, M., Chen, B., Eguchi, M., Kudo, T., Shrestha, S., (2001) J. Mol. Catal. B: Enzym. 16, 53-58.

[104] Li, S. F., Fan, Y. H., Hu, R. F., Wu, W. T., (2011) J. Mol. Catal. B: Enzym. 72, 40-45.

[105] Wang, X., Liu, X., Yan, X., Zhao, P., Ding, Y., Xu, P., (2011) PLOS One 6, 1-7. 


\section{Table and Figure Captions}

Figure 1: Interfacial activation of lipase on hydrophobic supports (lipases recognize the hydrophobic surfaces of the support similarly to those of their natural substrates and they undergo interfacial activation during immobilization).

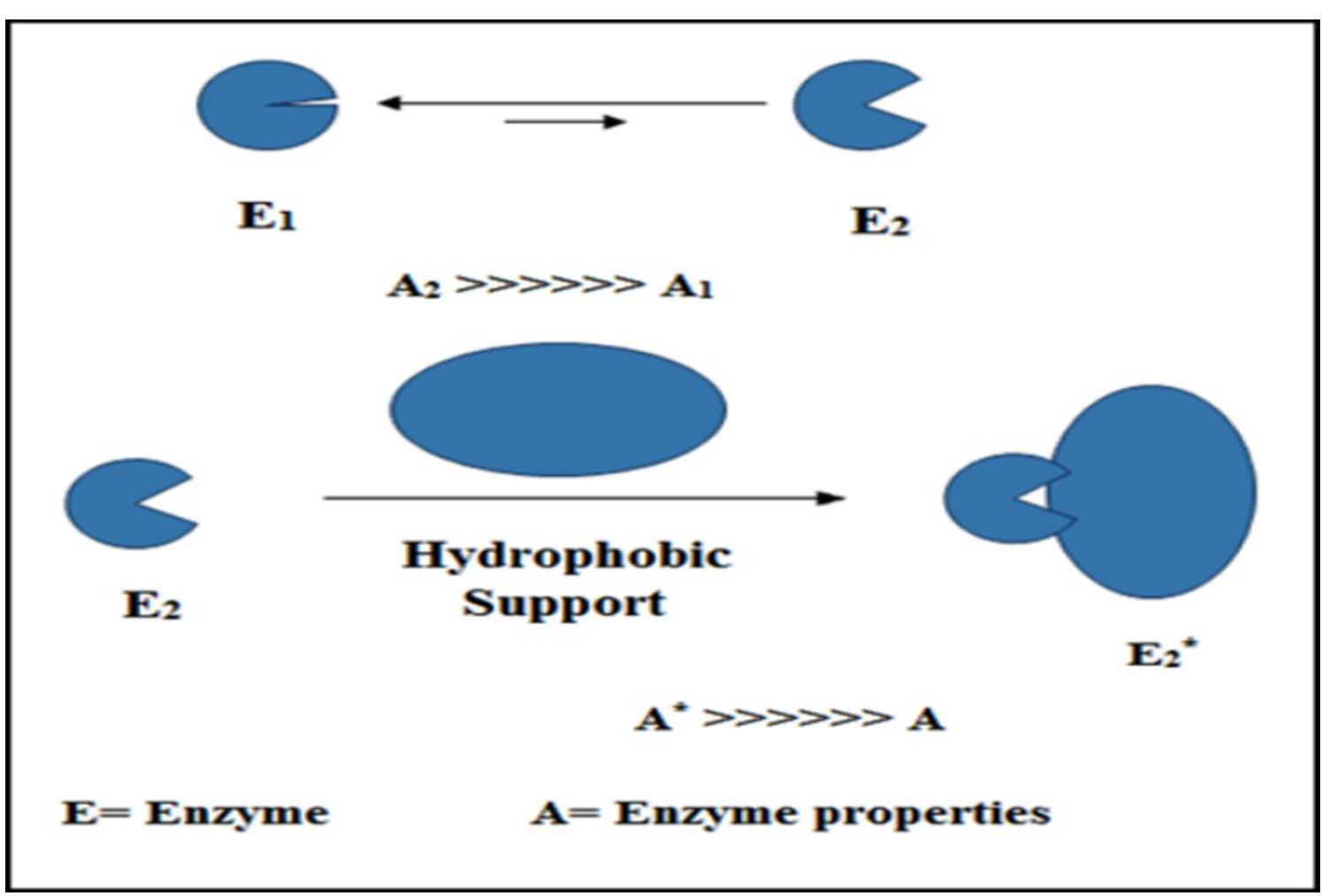

This article is protected by copyright. All rights reserved. 
Figure 2: Cleavage of dimers and immobilization on hydrophobic supports (in the absence of hydrophobic surfaces, molecules of lipase forms dimers, however a hydrophobic surface can split them again).



Figure 3: Common functional groups in lipase covalent coupling on nanomaterials.

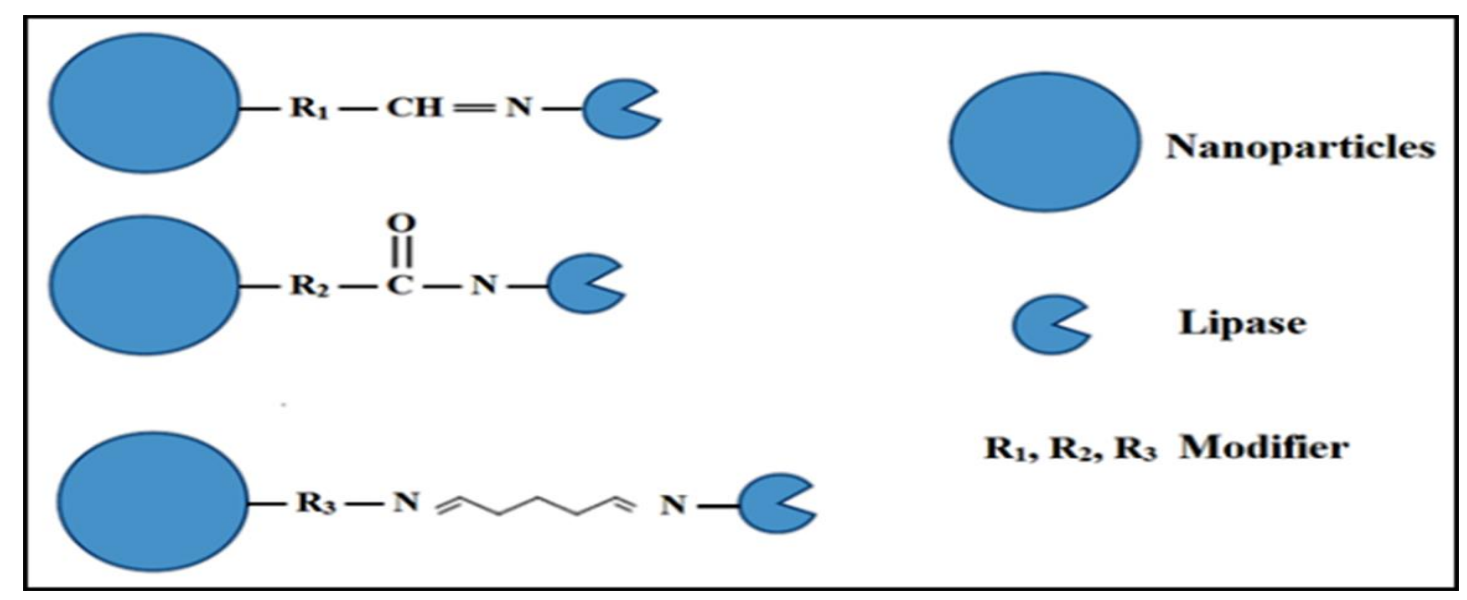

This article is protected by copyright. All rights reserved. 
Figure 4: A generalized biochemical reaction scheme of lipase substrate biosensor.

Reaction 1: Formation of n-butyl laurate in presence of lipases immobilized on chrysotile.

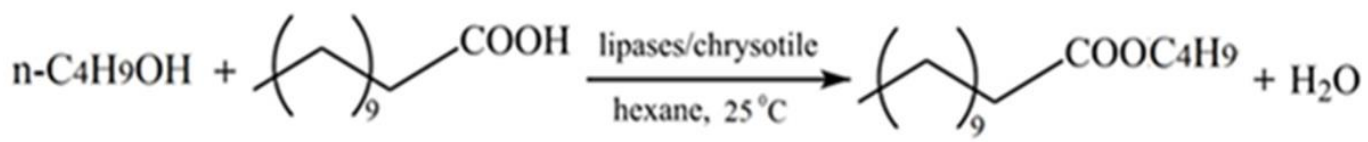

Reaction 2: Racemic resolution of chiral primary alcohols with Pseudomonas cepacia (PS) lipase

(Enzyme catalyzes the reaction of S-enantiomer with vinyl acetate which facilitate its separation from

R-enantiomer).

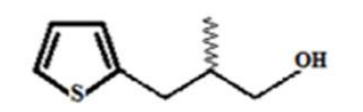

(R, S)-2-methyl-3-(2-thiophen)-propanol

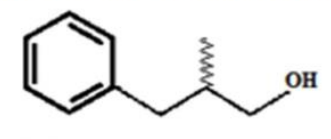

(R, S)-2-methyl-3-phenylpropanol



(S)-2-methyl-3-2-thiophen)-propyl acetate



(R)-2-methyl-3-phenylpropanol



(R)-2-methyl-3-(2-thiophen)-propanol

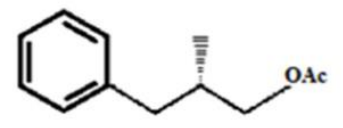

(S)-2-methyl-3-phenylpropyl acetate

This article is protected by copyright. All rights reserved. 
Table 1: Kinetic parameters of lipase in different research studies (nanostructured materials exhibited lower $\mathrm{K}_{\mathrm{m}}$ compared to micro-structured ones which is in favor of catalytic reactions).

\begin{tabular}{|c|c|c|c|c|c|c|}
\hline Source and support & Reaction & $\begin{array}{c}\mathbf{K}_{\mathbf{m}}{ }^{\mathbf{A}} \\
(\mathrm{mol} / \mathrm{L})\end{array}$ & $\begin{array}{c}\mathbf{K}_{\mathbf{m}}^{\mathbf{B}} \\
(\mathrm{mol} / \mathrm{L})\end{array}$ & $\begin{array}{c}\mathbf{K}_{\mathbf{I}} \\
(\mathrm{mol} / \mathrm{L})\end{array}$ & 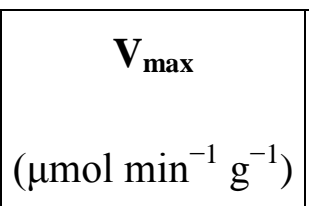 & Ref. \\
\hline $\begin{array}{c}\text { R. miehei } \\
\text { (Macroporous anionic resin) }\end{array}$ & Est $^{1}$ & $\begin{array}{c}3.03 \times \\
10^{-3}\end{array}$ & $\begin{array}{r}3.06 \\
\times 10^{-3}\end{array}$ & $\begin{array}{l}1.05 \text { (Acid) } \\
6.55 \text { (Alcohol) }\end{array}$ & $1.1720 \times 10^{4}$ & $(26)$ \\
\hline $\begin{array}{c}\text { C. Antarctica } \\
\text { (Macroporous acrylic resin) }\end{array}$ & $\mathrm{Act}^{2}$ & 0.26 & 0.96 & 1.39 & $5.2080 \times 10^{4}$ & $(27)$ \\
\hline $\begin{array}{c}\text { M. miehei } \\
\text { (Macroporous anionic resin) }\end{array}$ & Est & 0.190 & 0.120 & 0.04 & $5.7 \times 10^{3}$ & $(28)$ \\
\hline $\begin{array}{c}\text { C. Antarctica } \\
\text { (Macroporous acrylic resin) }\end{array}$ & Est & 0.104 & NA & NA & 43.5 & $(29)$ \\
\hline $\begin{array}{c}\text { C. rugosa } \\
\left(\mathrm{Fe}_{3} \mathrm{O}_{4} \text { magnetic } \mathrm{NPs}\right)\end{array}$ & $\mathrm{Hyd}^{3}$ & $\begin{array}{l}4 \times \\
10^{-4}\end{array}$ & NA & NA & $1.07 \times 10^{3}$ & $(30)$ \\
\hline $\begin{array}{l}\text { C. Antarctica } \\
\left(\mathrm{Fe}_{2} \mathrm{O}_{3} \mathrm{NPs}\right)\end{array}$ & Hyd & $\begin{array}{l}2.5 \times \\
10^{-2}\end{array}$ & NA & NA & $2.32 \times 10^{4}$ & $(31)$ \\
\hline
\end{tabular}




\begin{tabular}{|c|c|c|c|c|c|c|}
\hline $\begin{array}{c}\text { porcine pancreas } \\
\left(\mathrm{Fe}_{3} \mathrm{O}_{4} \text { magnetic } \mathrm{NPS}\right)\end{array}$ & $\mathrm{Hyd}$ & $1.2 \times$ & $\mathrm{NA}$ & $\mathrm{NA}$ & $5.6 \times 10^{2}$ & $(32)$ \\
\hline
\end{tabular}

This article is protected by copyright. All rights reserved. 
Table 2: Different nanoparticles used in lipase immobilization and their performance summary.

\begin{tabular}{|c|c|c|c|c|c|c|c|}
\hline Category & \multicolumn{2}{|c|}{ NPs } & $\begin{array}{c}\text { Immobilization } \\
\text { mechanism }\end{array}$ & $\begin{array}{c}\text { Particle } \\
\text { size } \\
(\mathbf{n m})\end{array}$ & $\begin{array}{c}\text { Activity } \\
\text { Retention } \\
(\%)\end{array}$ & $\begin{array}{c}\text { Recycling } \\
\text { Ability }\end{array}$ & Ref. \\
\hline \multirow{7}{*}{$\begin{array}{l}\text { Non } \\
\text { magnetic }\end{array}$} & \multicolumn{2}{|c|}{ Gold-Silica } & $\begin{array}{l}\text { Covalent } \\
\text { Coupling }\end{array}$ & $\begin{array}{c}15 \\
\text { (silica) } \\
\text { and } \\
2 \text { (gold) }\end{array}$ & 67 & N/A & (46) \\
\hline & \multirow{3}{*}{$\mathrm{SiO}_{2}$} & NSD-1 & \multirow{3}{*}{$\begin{array}{l}\text { Covalent } \\
\text { Coupling }\end{array}$} & N/A & 73 & N/A & \multirow{3}{*}{$(45)$} \\
\hline & & NSD-2 & & N/A & 79 & N/A & \\
\hline & & NSD-3 & & N/A & 118 & $\begin{array}{c}72 \% \\
15 \text { cycles }\end{array}$ & \\
\hline & \multicolumn{2}{|c|}{ Chitosan } & Entrapment & $<100$ & 113.17 & $\begin{array}{c}\text { Most } \\
\text { activity } \\
10 \text { cycles }\end{array}$ & (71) \\
\hline & \multirow{2}{*}{\multicolumn{2}{|c|}{ Chitosan }} & \multirow[t]{2}{*}{ Cross-Linking } & 7 & 66.7 & $\begin{array}{c}91 \% \\
5 \text { cycles }\end{array}$ & \multirow[t]{2}{*}{ (89) } \\
\hline & & & & 10 & 62.8 & N/A & \\
\hline \multirow[t]{4}{*}{ Magnetic } & \multicolumn{2}{|c|}{$\begin{array}{c}\text { Amino-Silane } \\
\text { modified } \\
\text { superparamagnetic } \\
\mathrm{Fe}_{3} \mathrm{O}_{4}\end{array}$} & $\begin{array}{l}\text { Covalent } \\
\text { Coupling }\end{array}$ & N/A & 58.2 & $\begin{array}{c}\text { above } \\
50 \% \\
10 \text { cycles }\end{array}$ & $(48)$ \\
\hline & \multicolumn{2}{|c|}{$\begin{array}{c}\mathrm{Fe}_{3} \mathrm{O}_{4} \text { treated with } \\
\text { (3-aminopropyl) } \\
\text { triethoxysilane }\end{array}$} & $\begin{array}{l}\text { Covalent } \\
\text { Coupling }\end{array}$ & 11.2 & 70 & $\begin{array}{c}89 \% \\
4 \text { cycles }\end{array}$ & $(47)$ \\
\hline & \multicolumn{2}{|c|}{$\begin{array}{c}\text { Hydrophobic } \\
\text { nano-sized } \\
\text { magnetite NPs }\end{array}$} & Adsorption & $10 \pm 2$ & $\begin{array}{c}155 \\
\text { (specific } \\
\text { activity) }\end{array}$ & $\begin{array}{l}\text { about } \\
50 \% 6 \\
\text { cycles }\end{array}$ & (41) \\
\hline & \multicolumn{2}{|c|}{$\begin{array}{c}\text { Polydopamine } \\
\text { modified iron oxide }\end{array}$} & $\begin{array}{l}\text { Covalent } \\
\text { Coupling }\end{array}$ & $50-250$ & $\begin{array}{c}73.9 \\
\text { (specific }\end{array}$ & $\begin{array}{c}70 \% \\
21 \text { cycles }\end{array}$ & (49) \\
\hline
\end{tabular}




\begin{tabular}{|c|c|c|c|c|c|c|c|}
\hline Category & \multicolumn{2}{|c|}{ NPs } & $\begin{array}{c}\text { Immobilization } \\
\text { mechanism }\end{array}$ & $\begin{array}{c}\text { Particle } \\
\text { size } \\
(\mathbf{n m})\end{array}$ & $\begin{array}{c}\text { Activity } \\
\text { Retention } \\
(\%)\end{array}$ & $\begin{array}{c}\text { Recycling } \\
\text { Ability }\end{array}$ & Ref. \\
\hline & & & & & activity) & & \\
\hline & \multicolumn{2}{|c|}{$\begin{array}{l}\text { Chitosan-coated } \\
\qquad \mathrm{Fe}_{3} \mathrm{O}_{4}\end{array}$} & $\begin{array}{l}\text { Covalent } \\
\text { Coupling }\end{array}$ & $<30$ & N/A & $\begin{array}{c}83 \% \\
20 \text { cycles }\end{array}$ & (59) \\
\hline & \multicolumn{2}{|c|}{$\begin{array}{l}\text { Oleic Acid-Pluronic } \\
\text { (L-64) Block } \\
\text { Copolymer Coated } \\
\text { Magnetic NPs }\end{array}$} & Adsorption & 10 & N/A & $\begin{array}{c}90 \% \\
7 \text { cycles }\end{array}$ & (76) \\
\hline & \multirow[b]{2}{*}{$\begin{array}{c}\mathrm{Fe}_{3} \mathrm{O}_{4-} \\
\text { Chitosan }\end{array}$} & $\begin{array}{l}\text { without } \\
\text { magnetic } \\
\text { field }\end{array}$ & \multirow[b]{2}{*}{ Adsorption } & $\sim 33$ & 101 & $\begin{array}{c}36.2 \% \\
8 \text { cycles }\end{array}$ & \multirow[b]{2}{*}{ (61) } \\
\hline & & $\begin{array}{l}\text { with } \\
\text { magnetic } \\
\text { field }\end{array}$ & & $\begin{array}{c}\text { Rod } \\
\text { like: } \\
\mathrm{D}= \\
\sim 38, \mathrm{~L}= \\
\sim 204\end{array}$ & 132 & $\begin{array}{c}46.3 \% \\
8 \text { cycles }\end{array}$ & \\
\hline & \multicolumn{2}{|c|}{$\mathrm{Fe}_{3} \mathrm{O}_{4}$-Chitosan } & Adsorption & 80 & 55.6 & $\begin{array}{c}88 \% \\
5 \text { cycles }\end{array}$ & (72) \\
\hline & \multicolumn{2}{|c|}{$\begin{array}{c}\text { Silica-coated } \\
\text { modified magnetite } \\
\text { NPs }\end{array}$} & $\begin{array}{l}\text { Covalent } \\
\text { Coupling }\end{array}$ & $17.5-21$ & $\sim 94$ & $\begin{array}{l}63.51 \% \\
6 \text { cycles }\end{array}$ & (63) \\
\hline & \multicolumn{2}{|c|}{$\begin{array}{c}\text { Lauric } \\
\text { acid-stabilized } \\
\text { magnetic NPs }\end{array}$} & $\begin{array}{l}\text { Covalent } \\
\text { Coupling }\end{array}$ & $<20$ & 180 & $\begin{array}{l}56.4 \% \\
7 \text { cycles }\end{array}$ & (98) \\
\hline & \multicolumn{2}{|c|}{$\begin{array}{c}\text { Polymer } \\
\text { modified- } \mathrm{Fe}_{3} \mathrm{O}_{4} \\
\mathrm{NPs}\end{array}$} & $\begin{array}{l}\text { Electrostatic } \\
\text { adsorption and } \\
\text { covalent } \\
\text { binding }\end{array}$ & $200-400$ & 70.4 & $\begin{array}{c}70 \% \\
5 \text { cycles }\end{array}$ & (65) \\
\hline
\end{tabular}

Abbreviations: NSD: nano-silica dioxide, D: Diameter, L: Length 
Table 3: Different nanotubes used in lipase immobilization and their performance summary.

\begin{tabular}{|c|c|c|c|c|c|}
\hline Category & $\begin{array}{l}\text { Immobilization } \\
\text { mechanism }\end{array}$ & Activity Retention (\%) & Stability & $\begin{array}{c}\text { Recycling } \\
\text { Ability }\end{array}$ & References \\
\hline \multirow[t]{7}{*}{ MWCNTS } & Covalent binding & $40-60$ & Increased by $58 \pm 7 \%$ & Reusable & (57) \\
\hline & Covalent binding & $76-82$ & Not mentioned & Reusable & (58) \\
\hline & Adsorption & 97 & Increased by 14 folds & $\begin{array}{l}\text { Not } \\
\text { mentioned }\end{array}$ & (59) \\
\hline & Adsorption & 85 & Not mentioned & $\begin{array}{l}\text { Not } \\
\text { mentioned }\end{array}$ & (60) \\
\hline & Adsorption & Not mentioned & Not mentioned & $\begin{array}{c}\text { Not } \\
\text { mentioned }\end{array}$ & (61) \\
\hline & Covalent binding & 57 & $\begin{array}{c}\text { Increased thermally stability } \\
\text { upto } 80^{\circ} \mathrm{C}\end{array}$ & 10 cycles & (62) \\
\hline & Covalent binding & $\begin{array}{c}79 \text { (with } \\
\text { carbodiimide) and } \\
30 \text { (with APTES and } \\
\text { SAA) }\end{array}$ & Not mentioned & 50 cycles & (63) \\
\hline \multirow[t]{2}{*}{ SWCNTS } & Covalent binding & \multirow{4}{*}{\multicolumn{2}{|c|}{ Not mentioned }} & & (64) \\
\hline & Reverse micelles & & & & (65) \\
\hline \multirow[t]{2}{*}{ NCNTs } & Covalent binding & & & & (66) \\
\hline & Adsorption & & & & (67) \\
\hline
\end{tabular}

Abbreviations: MWCNTs: Multi-walled carbon nanotubes, SWCNTs: single-walled carbon nanotubes, NCNTs: Non-carbon nanotubes, APTES: (3-Aminopropyl) triethoxysilane, SAA: Succinic acid anhydride.

This article is protected by copyright. All rights reserved. 
Table 4: Nanofibrous membranes used for lipase immobilization and their performance summary.

\begin{tabular}{|c|c|c|c|c|c|c|}
\hline $\begin{array}{c}\text { Mechanis } \\
\text { m }\end{array}$ & Material & $\begin{array}{c}\text { Diamete } \\
\mathbf{r} \\
(\mathbf{n m})\end{array}$ & $\begin{array}{c}\text { Protein } \\
\text { loading } \\
\text { (mg/g } \\
\text { nanomateria } \\
\text { l) }\end{array}$ & $\begin{array}{c}\text { Activity } \\
\text { retentio } \\
\text { n }(\%)\end{array}$ & $\begin{array}{c}\text { Reusabilit } \\
\mathbf{y}\end{array}$ & Ref \\
\hline \multirow{11}{*}{$\begin{array}{l}\text { Covalent } \\
\text { Coupling }\end{array}$} & $\begin{array}{c}\text { Functionalized } \\
\text { PANCMA }\end{array}$ & 100 & $21.2 \pm 0.71$ & $37.6 \pm 1.8$ & N/A & $\begin{array}{c}(77 \\
)\end{array}$ \\
\hline & $\begin{array}{c}\text { Chitosan-modified } \\
\text { PANCMA }\end{array}$ & 100 & $22.5 \pm 0.75$ & $45.6 \pm 1.8$ & $\begin{array}{c}55 \% \\
10 \text { cycles }\end{array}$ & $(78$ \\
\hline & $\begin{array}{c}\text { Gelatin-modified } \\
\text { PANCMA }\end{array}$ & 100 & $20.7 \pm 0.75$ & $49.7 \pm 1.8$ & $\begin{array}{c}60 \% \\
10 \text { cycles }\end{array}$ & ) \\
\hline & PANCMPC & $90 \pm 20$ & $22.9 \pm 1.5$ & $76.8 \pm 0.6$ & N/A & (79 \\
\hline & \multirow{2}{*}{ PAN } & \multirow{2}{*}{$150-300$} & $21.2 \pm 1.3$ & $81.3 \pm 1.1$ & $\begin{array}{c}70 \% \\
10 \text { cycles }\end{array}$ & $\begin{array}{c}(80 \\
)\end{array}$ \\
\hline & & & 21.2 & 87.5 & $\begin{array}{c}65 \% \\
20 \text { cycles }\end{array}$ & $\begin{array}{c}(81 \\
)\end{array}$ \\
\hline & $\begin{array}{l}\text { Epichlorohydrin } \\
\text { activated } \\
\text { PANCHEMA }\end{array}$ & \multirow{3}{*}{$80-150$} & $16.2 \pm 1.1$ & $\begin{array}{c}40.6 \pm \\
0.6\end{array}$ & \multirow{3}{*}{$\begin{array}{c}\sim 30 \% \\
10 \text { cycles }\end{array}$} & \multirow{3}{*}{$\begin{array}{c}(82 \\
)\end{array}$} \\
\hline & $\begin{array}{c}\text { Cyanuric chloride } \\
\text { activated } \\
\text { PANCHEMA }\end{array}$ & & $16.5 \pm 1.3$ & $\begin{array}{c}36.4 \pm \\
0.4\end{array}$ & & \\
\hline & $\begin{array}{l}\text { Benzoquinone } \\
\text { activated } \\
\text { PANCHEMA }\end{array}$ & & $15.5 \pm 1.2$ & $\begin{array}{c}32.5 \pm \\
0.8\end{array}$ & & \\
\hline & PANCAA & \multirow[b]{2}{*}{180} & 11.69 & 15.0 & $46 \%$ & \multirow{2}{*}{$\begin{array}{c}(83 \\
)\end{array}$} \\
\hline & $\begin{array}{c}\text { collagen-modified } \\
\text { PANCAA }\end{array}$ & & 9.15 & 61.7 & $62 \%$ & \\
\hline
\end{tabular}




\begin{tabular}{|c|c|c|c|c|c|c|}
\hline $\begin{array}{c}\text { Mechanis } \\
\text { m }\end{array}$ & Material & $\begin{array}{c}\text { Diamete } \\
\mathbf{r} \\
(\mathbf{n m})\end{array}$ & $\begin{array}{c}\text { Protein } \\
\text { loading } \\
\text { (mg/g } \\
\text { nanomateria } \\
\text { l) }\end{array}$ & $\begin{array}{c}\text { Activity } \\
\text { retentio } \\
\text { n }(\%)\end{array}$ & $\begin{array}{c}\text { Reusabilit } \\
\mathbf{y}\end{array}$ & Ref \\
\hline & $\begin{array}{c}\text { ES } \\
\text { hydrolysate-modifi } \\
\text { ed PANCAA }\end{array}$ & & 9.47 & 20.4 & $60 \%$ & \\
\hline & \multirow[t]{2}{*}{ Activated PAN } & NA & $43 \pm 4.0$ & 79.5 & $\begin{array}{c}91 \% \\
\text { (conversion } \\
\text { ) } \\
10 \text { cycles }\end{array}$ & $\begin{array}{c}(84 \\
)\end{array}$ \\
\hline & & $150-300$ & $43.4 \pm 4.0$ & 79 & $\begin{array}{c}98 \% \\
\text { (specific) } \\
10 \text { cycles } \\
\end{array}$ & $\begin{array}{c}(85 \\
)\end{array}$ \\
\hline & Chitosan & $80-150$ & 63.6 & 48.8 & $\begin{array}{c}46 \% \\
10 \text { cycles }\end{array}$ & $\begin{array}{r}(86 \\
)\end{array}$ \\
\hline Adsorption & CB-Cell & 200 & 16.21 & 86.2 & NA & $\begin{array}{c}(87 \\
)\end{array}$ \\
\hline
\end{tabular}

Abbreviations: PAN: Polyacrylonitrile; PANCMA: poly-(acrylonitrile-co-maleic acid); PANCMPC: poly [acrylonitrile-co-(2-methacryloyloxyethyl phosphorylcholine)]; PANCHEMA: Poly (acrylonitrile-co-2-hydroxyethyl methacrylate); CB-Cell: Cibacron Blue F3GA bound cellulose; PANCAA: poly (acrylonitrile-co-acrylic acid). 
Table 5: Advantages and disadvantages (in general) of using nanostructured support for lipase immobilization.

\begin{tabular}{|l|l|}
\hline \multicolumn{1}{|c|}{ Advantages } & \multicolumn{1}{c|}{ Disadvantages } \\
\hline Lower mass transfer resistance & Cost of fabrication \\
High surface area & Large scale application \\
High mechanical strength & $\begin{array}{l}\text { Separation of the reaction } \\
\text { medium }\end{array}$ \\
Diffusional problems minimization & \\
Easy to synthesize at high solids content with no need of & \\
surfactants or toxic reagents & \\
Homogeneous coating and well defined particles & \\
Adjustment of the particle size to fit within the working limits & \\
\hline
\end{tabular}

This article is protected by copyright. All rights reserved. 